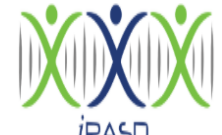

iRASD

Volume 9, Number 3, 2021, Pages 447-459

\title{
Energy Consumption and Economic Growth Nexus in Pakistan
}

Muhammad Ali Sindhu' ${ }^{1}$, Muhammad Abdul Quddus ${ }^{2}$

1 Ph.D. Scholar National College of Business Administration and Economics, Lahore, Pakistan. Email: muhammadalisindhu22@gmail.com

2 Professor/ Head of the Department, National College of Business Administration and Economics, Lahore, Pakistan. Email: draqmalik@gmail.com

\section{ARTICLE INFO}

Article History:

Received: $\quad$ November 11, 2021

Revised: $\quad$ December 19, 2021

Accepted: December 20, 2021

Available Online: December 22, 2021

\section{Keywords:}

Economic Growth

Primary EC

Electricity

Natural Gas

ARDL Bound Testing Approach

\section{Keywords:}

C01, 047, Q43

\section{ABSTRACT}

The study explored the link between energy consumption and economic growth in Pakistan covering the period from 1980 to 2018. This study used an augmented production function and combined the two neo-classical and ecological points. Most important is that this study used three different proxies of energy to check whether the relationship is proxy specific or not in Pakistan. Furthermore, there are some controls in terms of trade and foreign direct investment to check the robustness of the relationship. The time series approaches as augmented dickey fuller (ADF) unit root test and ARDL bound test approach has applied. The results indicated the long-run positive relationship between energy and growth in Pakistan and the relationship is not proxy specific. Therefore, it has suggested enhancing energy efficient policies, better resource allocation for energy supply.

(c) 2021 The Authors, Published by iRASD. This is an Open Access Article under the Creative Common Attribution Non-Commercial 4.0

Corresponding Author's Email: muhammadalisindhu22@gmail.com

\section{Introduction}

The sustainable development by 2030 is a major part of UN General Assembly's agenda. This agenda has many goals as sustainable energy for all as well. The motive of this energy goal is affordable, clean and modern energy with reliability. As there will be modern and clean energy around the globe, it will open new era of development in the whole world for both the developed and the developing countries. This development will open new economic opportunities and jobs creations; resultantly it will help to empowered women, children and youth in different parts of the world. When economic conditions are better off, it will help to provide reliable and improved medical and educational facilities (UnitedNations, 2021). Energy utilization helps to improve economic condition of country and strengthens the backbone of every country. In the development of any nation role of energy cannot be underestimated. As energy consumption (EC henceforth) increase in production sector of any developing country, it stimulates all the other economical factors of the economy affected positively to Economic Growth (EG henceforth).

Many studies have done to explore the major factors that effects EG in an economy considering energy as a new variable that was not included in conventional EG models. Neoclassical school of thought considered capital and labor as basic factors for growth: while endogenous growth theory took human capital in the system of neo-classical. On the other hand, with respect to ecological point of view, energy is very important factor of production and its importance cannot disregard in terms of a production function (Pirlogea \& Cicea, 2012; Stern, 2015).

Energy is important for economic betterment and 70's oil crisis confirmed the fact. In 1970 's developing countries decreased the supplies of raw material due to price hike and shortage of oil from oil extracting countries. Resultantly the developed countries suffered a lot as there was shortage of raw material for industries and prices were jumped in a short time (Razzaqi, Bilquees, \& Sherbaz, 2011; Yasar, 2017). According to ecological economics, energy 
is indispensable factor for production because "to change an input into output energy plays an important role". In traditional growth theories energy was given less importance and considered as a minor factor in production process. The thermodynamics laws describe that transformation of matter is possible only when a minimum quantity of energy is used (Stern, 1993; To, Wijeweera, \& Charles, 2013).

Energy plays its role in many aspects: as for economic development and social progress, industrialization, transformation in agriculture and most important environment in which people lived (Razzaqi et al., 2011). As "Energy" is fundamental element in any country's progress, so it should be considered as main input factor like other neo classical production factors capital (K) and labor (L) (Alaali, Roberts, \& Taylor, 2015; Stern, 2015). In current era of globalization, a quickly rising demand for energy shows that in future energy will be the most severe problem around the globe. It is necessary to find the substitute and inexhaustible sources to meet the future energy demands (IEA, 2019). Energy is essential component in both the consumption as well as production process in these days (Stern, 2004).

The importance of energy in case of Pakistan, like other developing countries assumes high place in enhancing economic growth. Several studies have established positive relationship indicating that energy has become another factor of production for instance, (Shaheen, Ginidi, El-Sehiemy, \& Ghoneim, 2020) and (Aqeel \& Butt, 2001; Razzaqi et al., 2011). Furthermore, the oil dependency that causes outflow of foreign exchange on one hand and the deterioration of the balance of Payment on the other hand also call for cheap and uninterested energy resources for the production process.

Energy is essential for country's development if growth hypothesis exists in an economy its mean that causality direction is from EC towards EG. Moreover, if direction of causality is vice versa, it supports the conservation hypothesis and energy saving strategies does not spur growth. In case of feedback hypothesis, both energy and economic activity are interlinked. Finally, neutrality hypothesis confirms that absence of any relationship (Payne, 2009).

The connection between economic expansion and energy utilization is a complex phenomenon as earlier studies witnessed for instance (Aqeel \& Butt, 2001; Khan \& Ahmad, 2008 ) in case of Pakistan and (Soytas, Sari, \& Ozdemir, 2001) in case of turkey among others. According to Payne (2009), there are four hypotheses neutrality, growth, feedback and conservation hypothesis existed in energy-growth relationship.

The contradiction in results requires reconsidering the relationship between EG and energy use in Pakistan. The purpose of study is to go over the long run as well as short-run relationship between EC and EG in Pakistan. In addition to this study used three different proxies of energy to check whether the relationship is proxy specific or not.

\section{Literature Review}

Ummalla and Goyari (2021) investigated the relationship in BRICS countries from 19922014. The countries that were part of analysis consisted of South Africa, China, India, Brazil and Russia. The variables are clean energy usage, economic activity measured by $\mathrm{EG}$ and $\mathrm{CO}_{2}$ emissions. The authors have applied Fisher-Johanson panel co-integration test and Fully Modified Ordinary Least Square (FMOLS) to check the relationship among variables. The results confirmed the existence of long run relationship among EG, clean EC and $\mathrm{CO}_{2}$ emissions.

Carfora, Pansini, and Scandurra (2019) studied the connection between three variables as energy prices, EC and growth in four countries. The data used for analysis from 1971-2015. The countries are Thailand, Philippines, Indonesia and India. They have applied Johansen multivariate maximum likelihood test for nature of the relationship in these countries. The results indicated the non-existence of relationship in EC, energy prices and EG in India and Indonesia, but bidirectional causality has been observed between energy price and income in both Philippines and Thailand. 
Aydin (2019) examined the relationship between EG, non-renewable electricity and renewable electricity consumption in 26 OECD countries. He has used the data covering the period from 1980-2015. The author has applied Panel Frequency Domain test and DumitrescuHurlin Panel Causality Test (2012) to find the relationship among variables. The results of Dumitrescu-Hurlin panel causality test indicated the two-way causality between non-renewable electricity consumption and EG, whereas neutrality hypothesis exists in renewable electricity consumption and EG. The results of Panel Frequency Domain test indicate the existence of bidirectional causality in both cases.

Khalid and Jalil (2019) explored the relationship between EC and EG in Pakistan. They have used different energy sources as natural gas, hydro electricity and coal to check its relation with EG considering time from 1980-2013. They have applied Trans-Log Production Function approach for analysis. The results show the positive association of all energy sources with EG in Pakistan. However, the policy recommendation is not align with the results.

Balcilar, Bekun, and Uzuner (2019) investigated the relationship between electricity consumption, $\mathrm{CO}_{2}$ emission and EG in Pakistan. The researcher has used data from 1971 to 2014 for econometric analysis and applied Maki co-integration test (2012), dynamic ordinary least square test (DOLS) and Todayamamoto Approach (T-Y Approach) for analysis. The results indicated a long run relationship exists among variables. There exists bidirectional causality. The causality runs from growth to electricity consumption. However, the positive link between carbon emission and electricity consumption demands theoretical justification.

Faisal, Tursoy, and Ercantan (2017) investigated the connection between EG and EC by employing Toda-Yamamoto approach for Belgium. The author has used yearly data from 1960 to 2012. The results indicated a long run relationship among variables and confirm the conservation hypothesis in Belgium.

In 2015, Alaali et al. (2015) did a study and they examined the effect of Human capital and EC on EG with neo classical growth model in developed and oil exporting countries. The authors have used panel data covering the period from 1981-2009 for 130 countries and GMM technique has applied for empirical analysis. The outcome of this study shows that health and education both have positive relationship with economic growth.

Dissanayaka (2014) checked the connection between EC and EG in Sri Lanka. The researcher has used annual data covering the time span from 1981-2012. The most commonly used approach Vector Error Correction Model (VECM) is applied for empirical analysis and results indicated that here exists a long run relationship.

Kalyoncu, Gürsoy, and Göcen (2013) estimated the relationship between GDP and EC. The sample consists of three countries as Georgia, Armenia, and Azerbaijan. The researchers have used time series data from 1995-2009. Per capita GDP and per capita EC have measured as constant $\$ 2000 \mathrm{US}$ and $\mathrm{kg}$ oil equivalent respectively. All variables have expressed in logarithmic form. Authors have applied ADF Dickey and Fuller (1979) and granger causality tests for estimation. In case of Georgia and Azerbaijan, there exists no co-integration relation whereas co-integration relation exists in Armenia. There is one-way causality running from per capita GDP to per capita EC.

Masuduzzaman (2012) explored the relationship between investment, EG and electricity consumption in Bangladesh. The author has used johansen co-integration test and time span from 1981 to 2011. The results indicated long run relationship among all variables. Moreover, there exists unidirectional causality. The causality runs from electricity consumption to EG and investment.

Noor and Siddiqi (2010) evaluated the causality among energy using up and economic expansion in five economies as Bangladesh, Nepal, India, Srilanka and Pakistan (South Asian countries). Estimation shows a unidirectional causality from GDP per capita to EC per capita in SR but negative relation has existed in long-run. When the structural breaks were considered as a factor, the results were not very different. These results also indicated the causality direction towards electricity consumption from EG (Dramani, Francis, \& Tewari, 2012; Shahbaz \& Feridun, 2012). 
Dhungel (2008) explored the link between EC and EG in case of Nepal covering annual data from 1980 to 2004. The author has applied Granger causality \& Johansen co-integration test. The findings of the paper show that there exists a unidirectional causality. The causality runs from energy to EG in Nepal.

Lee (2005) tried to establish the relationship between GDP and energy in eighteen developing nations covering the time from 1975-2001. The countries included were Pakistan, South Korea, Sri Lanka, Argentina, Hungry, Singapore, India, Chile, Ghana, Colombia, Kenya Mexico, Malaysia, Venezuela, Indonesia, Peru, Philippines and Thailand. Panel based Tests are used for analysis. The results indicated a one-way causal relationship running from EC to GDP in all economies.

In a study Asafu-Adjaye (2000) estimated the causal relationship between Real income, EC and Energy prices in developing countries (Thailand, India, Philippines and Indonesia) covering time from 1971 to 1995.The researcher has used co-integration and ECM technique. The results indicated that unidirectional causality exists in case of India and Indonesia, and it runs from energy to income. However, bidirectional causality was found in case of Thailand and Philippines.

After the literature review, it can safely be said that the results are not conclusive which means to say that the relationship between EC and EG is a complex phenomena. So to the best of our knowledge hardly any study used different proxies of energy. We contribute by using different proxies (Primary Energy Consumption, Electricity Consumption, Natural Gas Consumption) of energy that may be helpful in settling the debate about relationship between energy and economic growth.

\section{Data, Model and Methodology}

This study used annual data covering the period from 1980 to 2018 for empirical analysis. The dependent variable is GDP per capita while the independent variables are capital, Labor, EC, Government Expenditure, terms of trade and foreign investment. All variables are in log form except FDI. The data has taken from World Development Indicator (Bank, 2021) (WDI 2021), Economic Survey of Pakistan (Various Issues) and British Petroleum Statistical Review (Petroleum, 2020). The time series analysis approaches like ADF unit root test and ARDL Bounds Test Approach has applied.

According to Solow, there is constant return to aggregate production function and decreasing return to labor and capital (Solow, 1956). Solow's production function is given by

$$
Y=F(K, L)
$$

In addition, with the emergence of ecological economics, energy has also become another important factor of production (Stern, 2015).

$$
Y=F(K, L . E)
$$

General Form of model is given below;

$$
y_{t}=f\left(\beta_{0}+\beta_{1} x_{t}+\beta_{2} x_{2 t}+\varepsilon_{t}\right)
$$

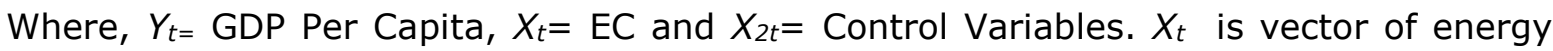
which includes primary EC per capita, electricity consumption and natural gas consumption whereas $X_{2 t}$ is the vector of control variables which includes capital, labor, terms of trade, government final consumption expenditure and foreign direct investment. The specific equations for each model are given below;

\section{Model I}

$$
\mathrm{LNGDPPC}_{t}=\beta_{0}+\beta_{1} \mathrm{LNGFCF}_{t}+\beta_{2} \mathrm{LNLFT}_{t}+\beta_{3} \mathrm{LNPECPC}_{t}+\beta_{4} \mathrm{LNGFCE}_{t}+\beta_{5} \mathrm{LNTOT}_{t}+\varepsilon_{t}----1
$$


In above model I, the dependent variable is GDP per capita and independent variables are Gross Fixed Capital Formation, Total Labor Force, Primary Energy Consumption per Capita, Government Final Consumption Expenditure and Terms of Trade. All variables are in log form.

\section{Model II}

$$
\text { LNGDPPC }_{t}=\beta_{0}+\beta_{1} \text { LNGFCF }_{t}+\beta_{2} \text { LNLFT }_{t}+\beta_{3} \text { LNELEC }_{t}+\beta_{4} \text { LNGFCE }_{t}+\beta_{5} \text { LNTOT }_{t}+\varepsilon_{\mathrm{t}}---2
$$

In this model II, the dependent variable is GDP per capita and independent variables are Gross Fixed Capital Formation, Total Labor Force, Electricity Consumption, Government Final Consumption Expenditure and Terms of Trade. All variables are in log form.

\section{Model III}

$$
\text { LNGDPPC }_{t}=\beta_{0}+\beta_{1} \mathrm{LNGFCF}_{t}+\beta_{2} \mathrm{LNLFT}_{t}+\beta_{3} \mathrm{LNNGC}_{t}+\beta_{4} \mathrm{LNGFCE}_{t}+\beta_{5} \mathrm{LNTOT}_{t}+\varepsilon_{\mathrm{t}} \ldots 3
$$

In model III, the dependent variable is GDP per capita and independent variables are Gross Fixed Capital Formation, Total Labor Force, Natural Gas Consumption, Government Final Consumption Expenditure and Terms of Trade. All variables are in log form.

\section{Model IV}

$$
\mathrm{LNGDPPC}_{t}=\beta_{0}+\beta_{1} \mathrm{LNGFCF}_{t}+\beta_{2} \mathrm{LNLFT}_{t}+\beta_{3} \mathrm{LNPECPC}_{t}+\beta_{4} \mathrm{LNGFCE}_{i}+\beta_{5} \mathrm{FDI}_{\mathrm{t}}+\varepsilon_{t} \ldots 4
$$

In this model IV, the dependent variable is GDP per capita and independent variables are Gross Fixed Capital Formation, Total Labor Force, Primary Energy Consumption per Capita, Government Final Consumption Expenditure and Foreign Direct Investment. All variables are in log form except foreign direct investment.

\section{Model V}

$$
\mathrm{LNGDPPC}_{t}=\beta_{0}+\beta_{1} \mathrm{LNGFCF}_{t}+\beta_{2} \mathrm{LNLFT}_{t}+\beta_{3} \mathrm{LNELEC}_{t}+\beta_{4} \mathrm{LNGFCE}_{t}+\beta_{5} \mathrm{FDI}_{t}+\varepsilon_{\mathrm{t}} \ldots 5
$$

In this model V, the dependent variable is GDP per capita and independent variables are Gross Fixed Capital Formation, Total Labor Force, Electricity Consumption, Government Final Consumption Expenditure and Foreign Direct Investment. All variables are in log form except foreign direct investment.

\section{Model VI}

$$
\mathrm{LNGDPPC}_{t}=\beta_{0}+\beta_{1} \mathrm{LNGFCF}_{t}+\beta_{2} \mathrm{LNLFT}_{t}+\beta_{3} \mathrm{LNNGC}_{t}+\beta_{4} \mathrm{LNGFCE}_{t}+\beta_{5} \mathrm{FDI}_{t}+\varepsilon_{\mathrm{t}} \ldots 6
$$

In this model VI, the dependent variable is GDP per capita and independent variables are Gross Fixed Capital Formation, Total Labor Force, Natural Gas Consumption, Government Final Consumption Expenditure and Foreign Direct Investment. All variables are in log form except foreign direct investment.

\section{Empirical Results and Discussion}

The unit-root test results are presented in table 1 show that the integration order of all variables is not same, some variables like LNGFCF and energy variable LNELEC is stationary at level while LNGDPPC LNLFT, LNPECPC, LNNGC, LNTOT, LNGFCE and FDI are stationary at $1^{\text {st }}$ difference; so the difference in order of integration, ARDL Bound testing approach proposed by (Pesaran, Shin, \& Smith, 2001) is appropriate technique for long run analysis of variables.

This set comprises three equation takes Government Final Consumption Expenditure and Terms of Trade as controls along with Capital and Labor that are theoretically wellgrounded concept from well-known Cobb-Dougles production function. The study has added variable of interest energy with three proxies to be confident that the results are proxy specific or not. In this set the purpose of adding two controls like; government final consumption expenditure and terms of trade to check the robustness of the relationship between EG and EC in Pakistan. 


\begin{tabular}{|c|c|c|c|c|c|c|c|}
\hline \multicolumn{8}{|c|}{$\begin{array}{c}\text { Augmented Dickey Fuller Test } \\
\qquad \begin{array}{c}\text { 1st Difference } \\
\end{array}\end{array}$} \\
\hline Variables & T-Stat & $\begin{array}{l}\text { CVs on diff } \\
\text { Significance } \\
\text { Level }\end{array}$ & P-Value & T-Stat & $\begin{array}{l}\text { CVs on diff } \\
\text { Significance } \\
\text { Level }\end{array}$ & P-Value & $\begin{array}{l}\text { Order of } \\
\text { Integration }\end{array}$ \\
\hline LNGDPPC & -0.28 & $\begin{array}{l}1 \% C V=-3.62 \\
5 \% C V=-2.94 \\
10 \% C V=-2.61 \\
1 \% C V=-4.24\end{array}$ & 0.9169 & -3.87 & $\begin{array}{l}1 \% C V=-3.62 \\
5 \% C V=-2.94 \\
10 \% C V=-2.61 \\
1 \% C V=-4.24\end{array}$ & 0.0005 & $\mathrm{I}(\mathrm{I})$ \\
\hline LNGFCF & -4.55 & $\begin{array}{l}5 \% \mathrm{CV}=-3.54 \\
10 \% \mathrm{CV}=-3.20\end{array}$ & 0.0046 & -- & $\begin{array}{l}5 \% \mathrm{CV}=-3.54 \\
10 \% \mathrm{CV}=-3.20\end{array}$ & -- & $\mathrm{I}(0)$ \\
\hline LNLFT & -0.82 & $\begin{array}{l}1 \% C V=-3.61 \\
5 \% C V=-2.94 \\
10 \% C V=-2.60 \\
1 \% C V=-3.61\end{array}$ & 0.9933 & -5.69 & $\begin{array}{l}1 \% C V=-3.62 \\
5 \% C V=-2.94 \\
10 \% C V=-2.61 \\
1 \% C V=-3.62\end{array}$ & 0.0000 & $\mathrm{I}(1)$ \\
\hline LNPECPC & -1.91 & $\begin{array}{l}5 \% \mathrm{CV}=-2.94 \\
10 \% \mathrm{CV}=-2.60 \\
1 \% \mathrm{CV}=-3.61\end{array}$ & 0.3202 & -7.17 & $\begin{array}{l}5 \% \mathrm{CV}=-2.94 \\
10 \% \mathrm{CV}=-2.61 \\
1 \% \mathrm{CV}=-3.61\end{array}$ & 0.0000 & $\mathrm{I}(\mathrm{I})$ \\
\hline LNELEC & -5.23 & $\begin{array}{l}5 \% \mathrm{CV}=-2.94 \\
10 \% \mathrm{CV}=-2.60\end{array}$ & 0.0001 & -- & $\begin{array}{l}5 \% \mathrm{CV}=-2.94 \\
10 \% \mathrm{CV}=-2.60\end{array}$ & -- & $\mathrm{I}(0)$ \\
\hline NNGC & -1.89 & $\begin{array}{l}1 \% C V=-3.61 \\
5 \% C V=-2.94 \\
10 \% C V=-2.60 \\
1 \% C V=-3.61\end{array}$ & 0.3310 & -5.41 & $\begin{array}{l}1 \% C V=-3.62 \\
5 \% C V=-2.94 \\
10 \% C V=-2.61 \\
1 \% C V=-3.62\end{array}$ & 0.0001 & $\mathrm{I}(\mathrm{I})$ \\
\hline LNGFCE & -2.11 & $\begin{array}{l}5 \% \mathrm{CV}=-2.94 \\
10 \% \mathrm{CV}=-2.60 \\
1 \% \mathrm{CV}=-3.61\end{array}$ & 0.2404 & -8.44 & $\begin{array}{l}5 \% \mathrm{CV}=-2.94 \\
10 \% \mathrm{CV}=-2.61 \\
1 \% \mathrm{CV}=-3.62\end{array}$ & 0.0000 & $\mathrm{I}(\mathrm{I})$ \\
\hline LNTOT & -2.61 & $\begin{array}{l}5 \% \mathrm{CV}=-2.94 \\
10 \% \mathrm{CV}=-2.60 \\
1 \% \mathrm{CV}=-3.62\end{array}$ & 0.0993 & -8.09 & $\begin{array}{l}5 \% \mathrm{CV}=-2.94 \\
10 \% \mathrm{CV}=-2.61 \\
1 \% \mathrm{CV}=-3.62\end{array}$ & 0.0000 & $\mathrm{I}(\mathrm{I})$ \\
\hline FDI & -2.90 & $\begin{array}{l}5 \% \mathrm{CV}=-2.94 \\
10 \% \mathrm{CV}=-2.61\end{array}$ & 0.0538 & -4.03 & $\begin{array}{l}5 \% \mathrm{CV}=-2.94 \\
10 \% \mathrm{CV}=-2.61\end{array}$ & 0.0034 & $\mathrm{I}(\mathrm{I})$ \\
\hline
\end{tabular}

Table 2: ARDL Bounds Testing Approach for Pakistan

\begin{tabular}{|c|c|c|c|c|c|}
\hline \multirow{2}{*}{ F-Statistics } & \multirow{2}{*}{$\begin{array}{l}\text { Model I } \\
4.48\end{array}$} & \multirow{2}{*}{ Model II } & \multicolumn{3}{|c|}{ Model III } \\
\hline & & & 4. 44 & 4.62 & \\
\hline Significance & $\mathrm{I}(0)$ Bound & I(1)Bound I(0) Bound & I(1)Bound & $\mathrm{I}(0)$ Bound & I(1)Bound \\
\hline $10 \%$ & 2.51 & 3.72 & 3.72 & 2.53 & 3.77 \\
\hline $5 \%$ & 2.99 & 4.41 & 4.41 & 3.05 & 4.46 \\
\hline
\end{tabular}

The value of F-Statistics in the first model is 4.48 , in the second model the value is 4.44 and in the third model its 4.62. All these values are greater than the upper bound critical values at $5 \%$ significance level, so we reject the null hypothesis of no cointegration and conclude that co-integration is present among the variables.

Table 3 shows the long run result of using energy and its effects on growth of Pakistan. In the first model, proxy of energy Primary EC is positive and statistically significant. The results are in line with the previous study done by (Wang \& Wang, 2020) in three countries like China, India, and United States. In the second model, proxy of energy is electricity consumption and it is found statistically significant and having a positive relationship with growth as previous literature witnessed in less developed country like Pakistan (Churchill, Inekwe, \& Ivanovski, 2020). In the third model, the study took natural gas consumption for representation of energy. The results indicated significant relationship between energy and growth as well and the relationship is positive as well (Jiang, Yang, \& Huang, 2020) and (Khalid \& Jalil, 2019). In all three models, control variables like GFCF, LFT, GFCE and TOT have positive link with economic growth. The results indicate that the estimated first period lagged of error term ECM is negative and statistically significant in first, second and third model. The presence of long run relationship is confirmed by value of error correction term. 
Table 3: ARDL Long Run Results

Dependent Variable: LNGDPPC

Regressors

MODEL I

MODEL II

MODEL III

\section{LNGFCF}

LNLFT Coefficients [Prob]

Coefficients

Coefficients [Prob]

LNGFCE

.082082

[.157]

.26817

$[.000]$

.57988

.16208

LNPECPC .36921

$[.000]$

.11486

$[.000]$

LNELEC

LNNGC

$-$

LNTOT

$-$

C

.014470

$\begin{array}{ll}- & .14707\end{array}$

$-$

$(.097)$

$-$

2.4647

$(.027)$

.019645

$(0.00)$

$-1.8365$

$[.000]$
$[.000]$
$[.000]$
-
$[.000]$

.29492

[.000]

.51897

.20602

$[.000]$

[.000]

ECT

$-0.83$

$-0.75$

0.99

Adjusted $\mathbf{R}^{\mathbf{2}}$

0.99

F-Statistics Prob

872.34

[.000]

1078.2

[.000]

(.021) $\quad .048815$

$\begin{array}{ll}(.027) & -2.5998\end{array}$

[.079]

$(0.00)$

$-0.80$

$(0.00)$

S.E. of regression 010447 .0093989

0.99

454.97

[.000]

\section{Model I}

Plot of Cumulative Sum of Recursive Residuals

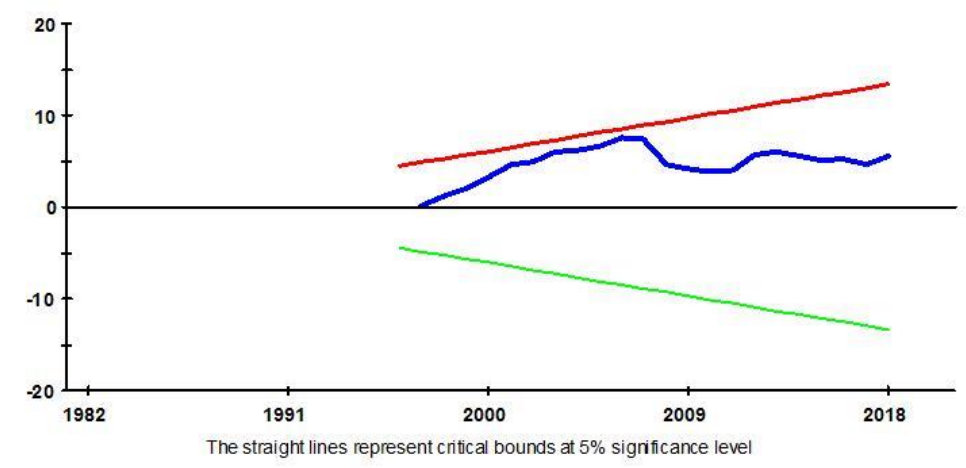

Plot of Cumulative Sum of Squares of Recursive Residuals

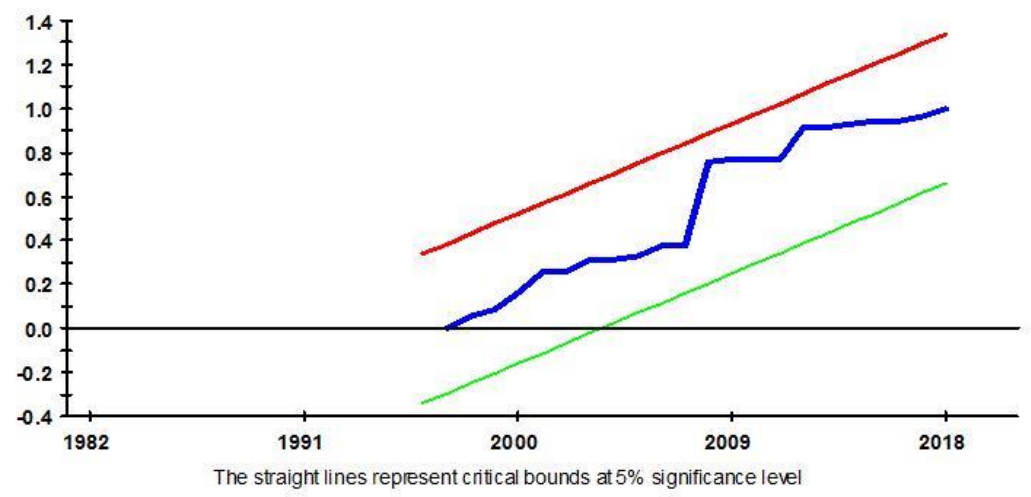




\section{Model II}

Plot of Cumulative Sum of Recursive Residuals

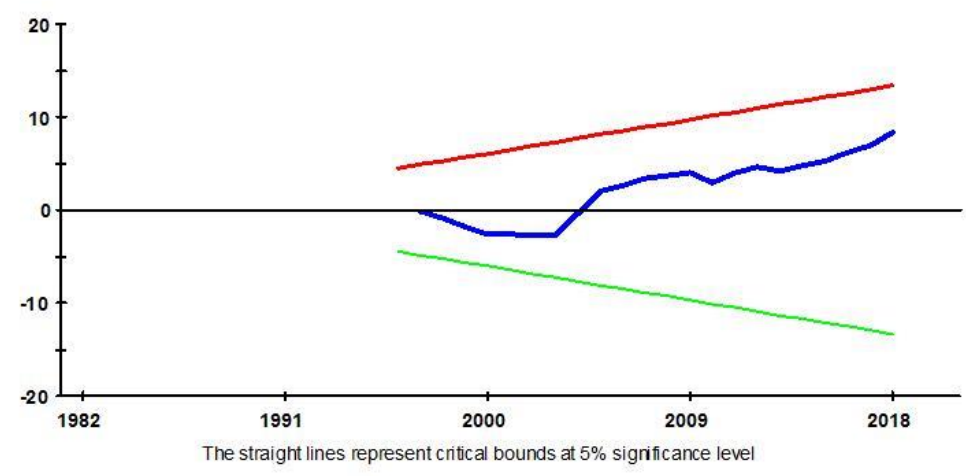

Plot of Cumulative Sum of Squares of Recursive Residuals

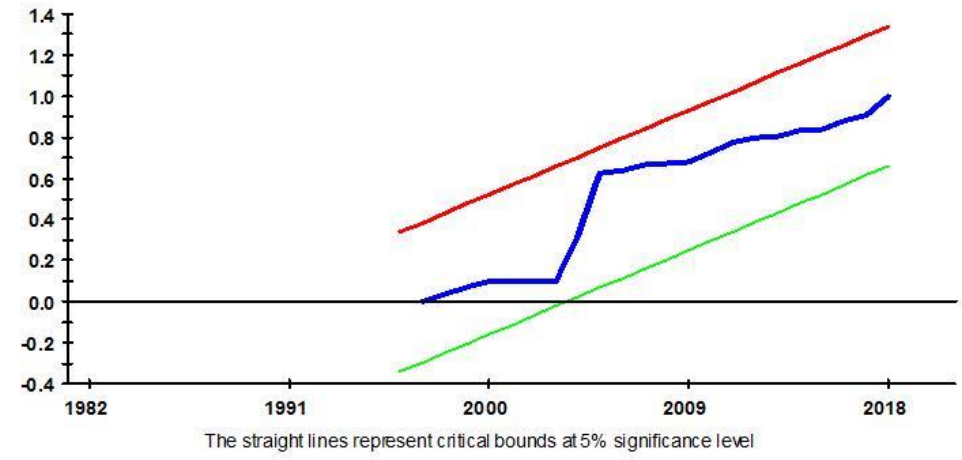

\section{Model III}

Plot of Cumulative Sum of Recursive Residuals

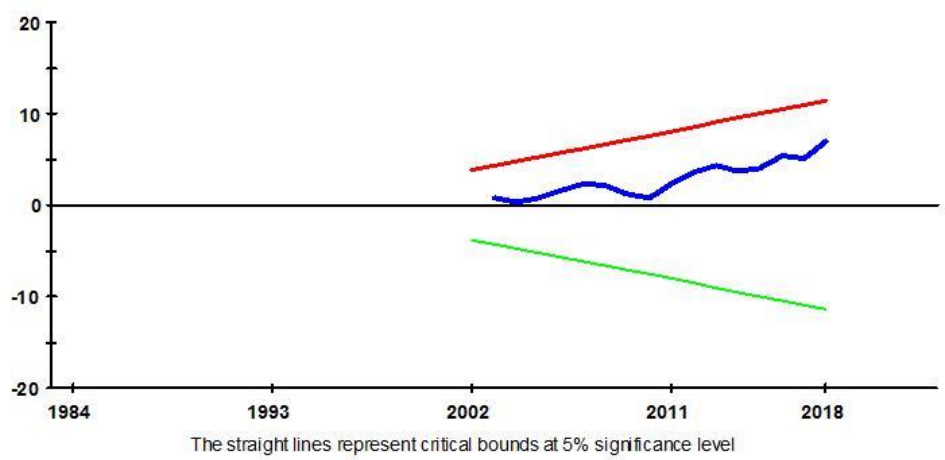

Plot of Cumulative Sum of Squares of Recursive Residuals

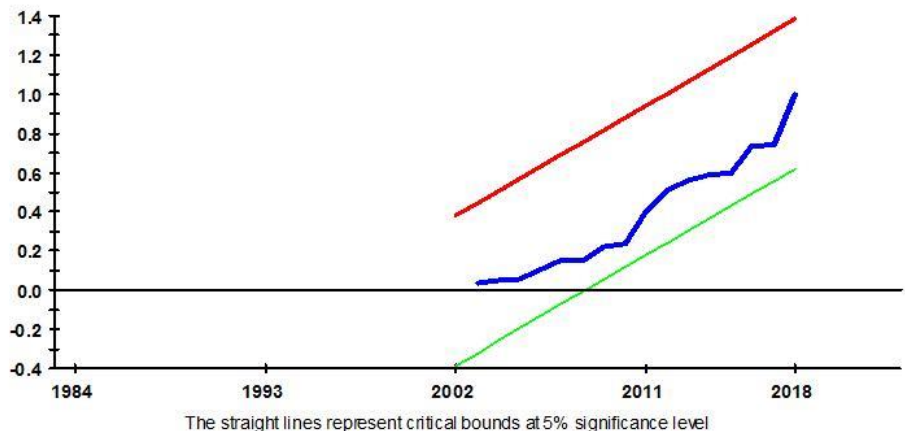

Since all the lines have not crossed the critical boundaries at 5 percent significance level in all the three models. Hence, $\mathrm{H}_{0}$ is not rejected and it is concluded that there is no 
structural break in data and parameters are stable. This second set comprises three equation takes Government Final Consumption Expenditure and Foreign Direct Investment as controls along with Capital and Labor that are theoretically well-grounded concept from well-known Cobb-Dougles production function. The study has added variable of interest energy with three proxies to be confident that the results are proxy specific or not. In this set the purpose of adding two controls like; government final consumption expenditure and foreign direct investment to check the robustness of the relationship between EG and EC in Pakistan.

Table 4: ARDL Bounds Testing Approach for Pakistan

\begin{tabular}{lccc}
\hline F-Statistics & Model IV & Model V & Model VI \\
& 5.16 & 6.80 & 4.98 \\
\hline
\end{tabular}

\begin{tabular}{cccccccc}
\hline Significance & $\mathbf{I}(\mathbf{0})$ & Bound & $\mathbf{I}(\mathbf{1})$ Bound & $\mathbf{I}(\mathbf{0})$ Bound & $\mathbf{I}(\mathbf{1})$ Bound & $\mathbf{I}(\mathbf{0})$ Bound & $\mathbf{I}(\mathbf{1})$ Bound \\
$10 \%$ & 2.52 & 3.73 & 2.53 & 3.77 & 2.53 & 3.77 \\
$5 \%$ & 3.01 & 4.42 & 3.05 & 4.46 & 3.05 & 4.46 \\
\hline
\end{tabular}

The value of F-Statistics in the fourth model is 5.16 , in the fifth model the value is 6.80 and in the last model number six it is 4.98. All these values are greater than the upper bound critical values at $5 \%$ significance level, so we reject the null hypothesis of no cointegration and conclude that co-integration is present among the variables.

Table 5 shows the long run result between EC and EGin Pakistan. In model IV, proxy of energy Primary EC is positive and statistically significant. The results are in line with the previous study done by (Wang \& Wang, 2020) in three countries like China, India and United States. In model $V$, the study used electricity consumption as proxy of energy and found statistically significant and positive relationship between energy and growth as previous literature witnessed in less developed country like Pakistan (Ahmad et al., 2020). In model VI, the study took natural gas consumption for representation of energy. The results indicated positive and significant relationship between energy and growth as well (Rahman \& Velayutham, 2020).

Table 5: ARDL Long Run Results

Dependent Variable: LNGDPPC

39 Observations used for the estimation from 1980 to 2018

\begin{tabular}{|c|c|c|c|c|c|c|}
\hline Regressors & $\begin{array}{l}\text { MODELIV } \\
\text { Coefficients }\end{array}$ & [Prob] & $\begin{array}{l}\text { MODEL V } \\
\text { Coefficients }\end{array}$ & [Prob] & $\begin{array}{l}\text { MODEL VI } \\
\text { Coefficients }\end{array}$ & [Prob] \\
\hline LNGFCF & .09612 & {$[.072]$} & .49561 & {$[.001]$} & .61513 & {$[.011]$} \\
\hline LNLFT & .33905 & {$[.000]$} & .74270 & {$[.000]$} & .49621 & {$[.008]$} \\
\hline LNGFCE & .15298 & {$[.000]$} & .10458 & {$[.002]$} & .15546 & {$[.018]$} \\
\hline LNPECPC & .44269 & {$[.000]$} & - & J & - & - \\
\hline LNELEC & - & - & .13245 & [.002] & - & - \\
\hline LNNGC & - & - & - & - & .26948 & [.004] \\
\hline FDI & -.01633 & {$[.024]$} & -.02206 & {$[.025]$} & -.069571 & {$[.009]$} \\
\hline C & 3.0668 & {$[.000]$} & -4.7378 & {$[.025]$} & -3.6257 & [.228] \\
\hline ECT & -0.89 & {$[.000]$} & -0.76 & {$[0.00]$} & -0.55 & {$[0.00]$} \\
\hline Adjusted $\mathbf{R}^{2}$ & 0.99 & & 0.99 & & 0.99 & \\
\hline F-Statistics Prob & 35723.0 & & 43837.7 & & 20901.5 & \\
\hline 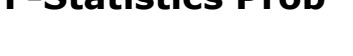 & {$[.000]$} & & {$[.000]$} & & {$[.000]$} & \\
\hline S.E. of regression & .010421 & & .0078497 & & .011663 & \\
\hline
\end{tabular}

In all three models controls variables like GFCF, LFT and GFCE are positive and statistically significant however, FDI turns out to be negative and statistically significant. This is strange and demands further investigation. The results indicate that the estimated first period lagged of error term ECM is negative and statistically significant in first, second and third model. This depicts that there is a long run relationship among the variables. 


\section{Model IV}

Plot of Cumulative Sum of Recursive Residuals

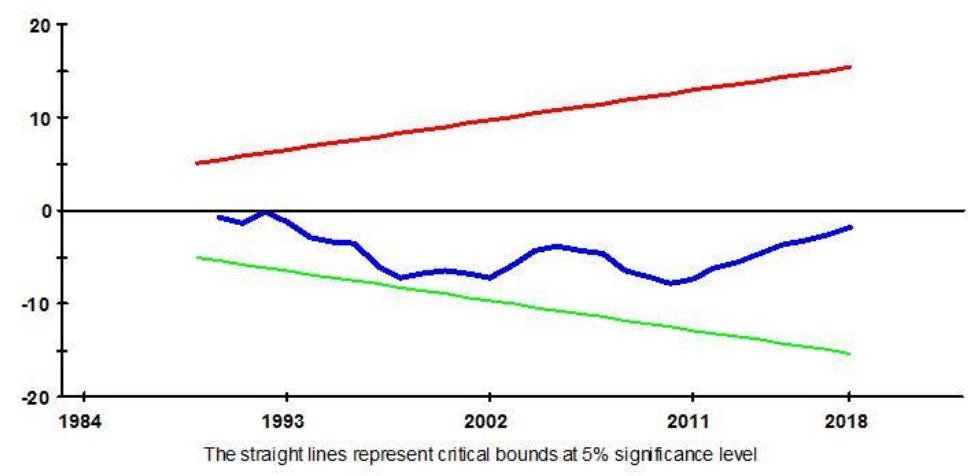

Plot of Cumulative Sum of Squares of Recursive Residuals

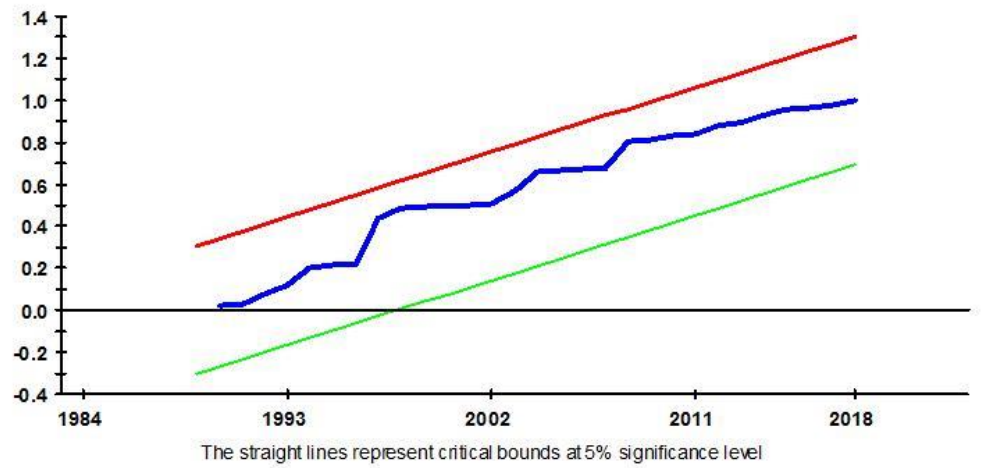

Since all the lines have not crossed the critical boundaries at 5 percent significance level in all the three models. Hence, the null hypothesis is not rejected and it is concluded that the parameters are stable and there is no structural break in the data in case of Pakistan.

\section{Model V}

Plot of Cumulative Sum of Recursive Residuals

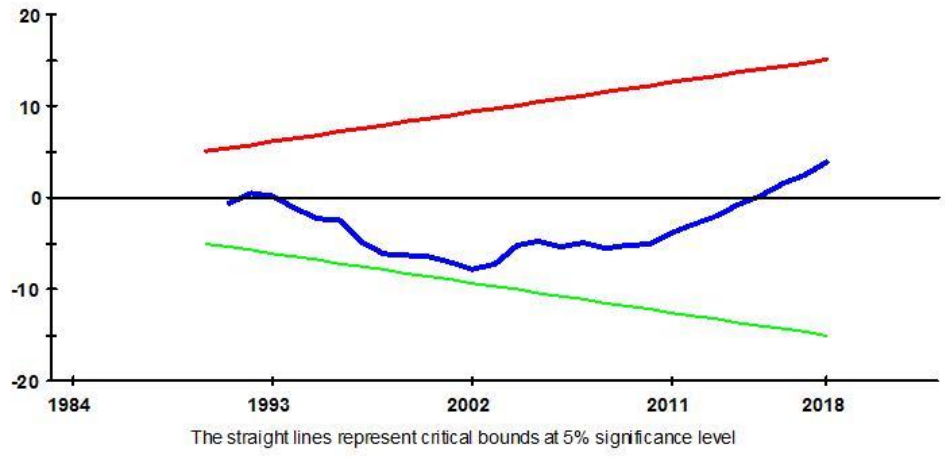




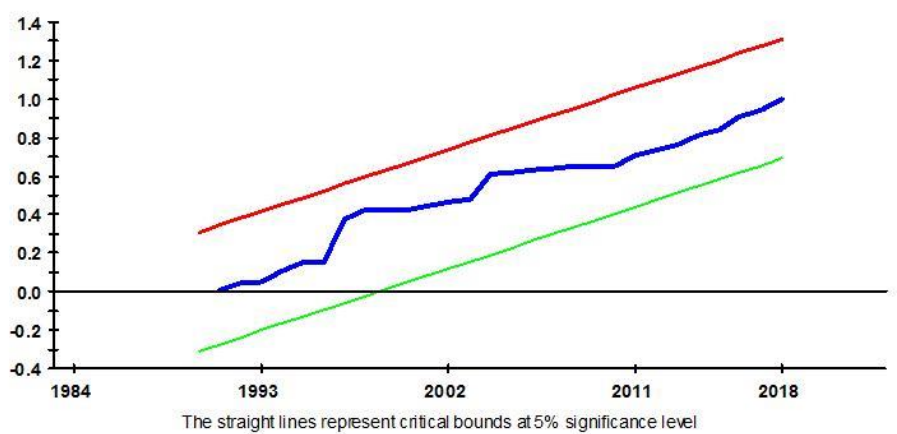

\section{Model VI}

Plot of Cumulative Sum of Recursive Residuals

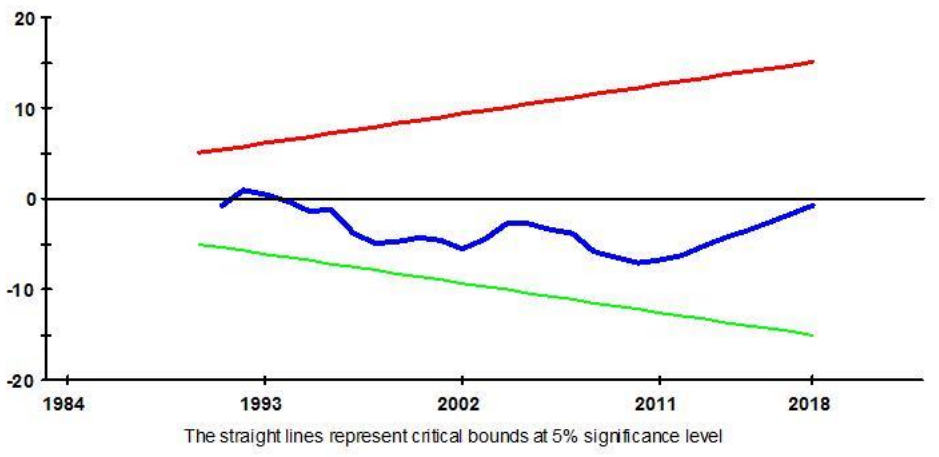

Plot of Cumulative Sum of Squares of Recursive Residuals

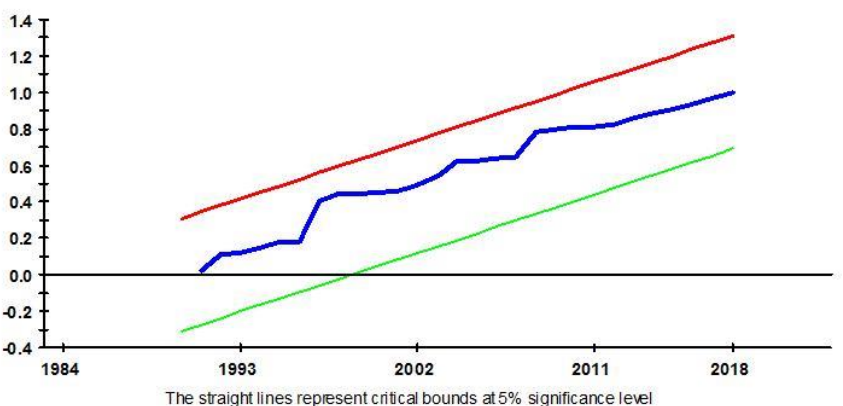

\section{Conclusion}

The study explores the link between EC and economic growth in Pakistan covering the period from 1980 to 2018 . This study used augmented production function and combined the two neo classical and ecological point. Most important is that this study used three different proxies of energy to check whether the relationship is proxy specific or not in Pakistan. Furthermore, there are some controls as terms of trade and foreign direct investment to check the robustness of the relationship. The time series approaches as augmented dickey fuller (ADF) unit root test and ARDL bound test approach has been applied for empirical analysis.

The results indicated that relationship of EC is positive with economic growth, irrespective of the proxy used. Irrespective of the source of energy is being used there exists a positive link between energy and economic growth in developing country like Pakistan. The results are also robust as the robustness checked by using TOT and FDI reveals. Regarding the diagnostic tests, it is evident that the parameters are stable across time as depicted by the Cumulative Sum (CUSUM) as well as Cumulative Sum of Square (CUSUMSQ). This parameter stability makes result suitable for the policy implications.

\section{Recommendations}

The econometric results showed that for growth of Pakistan, importance of energy cannot be underestimated as the positive relationship between each proxy of energy and 
growth appeared. Therefore, government should work for uninterrupted energy supply, particularly primary energy since the magnitude of its coefficient is higher than other energy sources.

\section{References}

Ahmad, M., Jabeen, G., Irfan, M., Mukeshimana, M. C., Ahmed, N., \& Jabeen, M. (2020). Modeling causal interactions between energy investment, pollutant emissions, and economic growth: China study. Biophysical Economics and Sustainability, 5(1), 1-12. doi: $10.1007 / \mathrm{s} 11356-018-3054-3$

Alaali, F., Roberts, J., \& Taylor, K. (2015). The effect of energy consumption and human capital on economic growth: an exploration of oil exporting and developed countries. SERPS (Sheffield Economics Research Papers Series)(015).

Aqeel, A., \& Butt, M. S. (2001). The relationship between energy consumption and economic growth in Pakistan. Asia-Pacific Development Journal, 8(2), 101-110.

Asafu-Adjaye, J. (2000). The relationship between energy consumption, energy prices and economic growth: time series evidence from Asian developing countries. Energy economics, 22(6), 615-625.

Aydin, M. (2019). Renewable and non-renewable electricity consumption-economic growth nexus: evidence from OECD countries. Renewable energy, 136, 599-606.

Balcilar, M., Bekun, F. V., \& Uzuner, G. (2019). Revisiting the economic growth and electricity consumption nexus in Pakistan. Environmental Science and Pollution Research, 26(12), 12158-12170.

Bank, T. W. (2021). Retrieved from https://data.worldbank.org/

Carfora, A., Pansini, R. V., \& Scandurra, G. (2019). The causal relationship between energy consumption, energy prices and economic growth in Asian developing countries: A replication. Energy Strategy Reviews, 23, 81-85.

Churchill, S. A., Inekwe, J., \& Ivanovski, K. (2020). Stochastic convergence in per capita CO2 emissions: Evidence from emerging economies, 1921-2014. Energy economics, 86, 104659. doi:10.1016/j.eneco.2019.104659

Dhungel, K. R. (2008). A Causal Relationship between Energy Consumption and Economic Growth in Nepal. Asia-Pacific Development Journal, 15, 137-150.

Dickey, D. A., \& Fuller, W. A. (1979). Distribution of the Estimators for Autoregressive Time Series With a Unit Root. Journal of the American Statistical Association, 74(366), 427431. doi: $10.2307 / 2286348$

Dissanayaka, D. M. A. (2014). Energy consumption and Economic Growth: Assessing the Evidence from Sri Lanka. Proc. of the Second Intl. Conf. on Advances In Social Science, Economics and Management Study SEM 2014. doi:10.15224/ 978-1-63248-052-1-78

Dramani, J. B., Francis, T., \& Tewari, D. (2012). Structural breaks, electricity consumption and economic growth: Evidence from Ghana. African Journal of Business Management, 6(22), 6709-6720.

Faisal, F., Tursoy, T., \& Ercantan, O. (2017). The relationship between energy consumption and economic growth: Evidence from non-Granger causality test. Procedia computer science, 120, 671-675.

IEA. (2019). World Energy Outlook 2019. Retrieved from https://www.iea.org/reports/worldenergy-outlook-2019

Jiang, T., Yang, J., \& Huang, S. (2020). Evolution and driving factors of CO2 emissions structure in China's heating and power industries: The supply-side and demand-side dual perspectives. Journal of Cleaner Production, 264, 121507. doi: $10.1016 / j$.jclepro.2020.121507

Kalyoncu, H., Gürsoy, F., \& Göcen, H. (2013). Causality relationship between GDP and energy consumption in Georgia, Azerbaijan and Armenia. International Journal of Energy Economics and Policy, 3(1), 111-117.

Khalid, W., \& Jalil, A. (2019). An econometric analysis of inter-fuel substitution in energy sector of Pakistan. Environmental Science and Pollution Research, 26(17), 1702117031.

Khan, M. A., \& Ahmad, U. (2008). Energy demand in Pakistan: a disaggregate analysis. The Pakistan Development Review, 437-455.

Lee, C.-C. (2005). Energy consumption and GDP in developing countries: a cointegrated panel analysis. Energy economics, 27(3), 415-427. 
Masuduzzaman, M. (2012). Electricity consumption and economic growth in Bangladesh: Cointegration and causality analysis. Global Journal of Management and Business Research, 12(11), 46-56.

Noor, S., \& Siddiqi, M. (2010). Energy consumption and economic growth in South Asian countries: a co-integrated panel analysis. International Journal of Energy and Power Engineering, 4(7), 1731-1736.

Payne, J. E. (2009). On the dynamics of energy consumption and employment in Illinois. Journal of Regional Analysis and Policy, 39(1100-2016-89639).

Pesaran, M. H., Shin, Y., \& Smith, R. J. (2001). Bounds testing approaches to the analysis of level relationships. Journal of applied econometrics, 16(3), 289-326.

Petroleum, B. (2020). Statistical Review of World Energy [Data set]. In.

Pirlogea, C., \& Cicea, C. (2012). Econometric perspective of the energy consumption and economic growth relation in European Union. Renewable and Sustainable Energy Reviews, 16(8), 5718-5726. doi:https://doi.org/10.1016/j.rser.2012.06.010

Rahman, M. M., \& Velayutham, E. (2020). Renewable and non-renewable energy consumption-economic growth nexus: new evidence from South Asia. Renewable Energy, 147, 399-408. doi:10.1016/j.renene.2019.09.007

Razzaqi, S., Bilquees, F., \& Sherbaz, S. (2011). Dynamic relationship between energy and economic growth: evidence from D8 countries. The Pakistan Development Review, 437458.

Shahbaz, M., \& Feridun, M. (2012). Electricity consumption and economic growth empirical evidence from Pakistan. Quality \& Quantity, 46(5), 1583-1599.

Shaheen, A. M., Ginidi, A. R., El-Sehiemy, R. A., \& Ghoneim, S. S. (2020). Economic power and heat dispatch in cogeneration energy systems using manta ray foraging optimizer. IEEE Access, 8, 208281-208295. doi:10.1109/ACCESS.2020.3038740

Solow, R. M. (1956). A contribution to the theory of economic growth. The quarterly journal of economics, 70(1), 65-94.

Soytas, U., Sari, R., \& Ozdemir, O. (2001). Energy consumption and GDP relation in Turkey: a cointegration and vector error correction analysis. Economies and business in transition: facilitating competitiveness and change in the global environment proceedings, 1 , 838-844.

Stern, D. I. (1993). Energy and economic growth in the USA: a multivariate approach. Energy economics, 15(2), 137-150.

Stern, D. I. (2004). Economic growth and energy. Encyclopedia of energy, 2(00147), 35-51.

Stern, D. I. (2015). The role of energy in economic growth. International energy and poverty, 35-47.

To, H., Wijeweera, A., \& Charles, M. B. (2013). Energy Consumption and Economic Growth@ The Case of Australia.

Ummalla, M., \& Goyari, P. (2021). The impact of clean energy consumption on economic growth and $\mathrm{CO} 2$ emissions in BRICS countries: Does the environmental Kuznets curve exist? Journal of Public Affairs, 21(1), e2126.

UnitedNations. (2021). THE 17 GOALS. Retrieved from https://sdgs.un.org/goals/goal7

Wang, Q., \& Wang, S. (2020). Preventing carbon emission retaliatory rebound post-COVID-19 requires expanding free trade and improving energy efficiency. Science of The Total Environment, 746, 141158. doi:10.1016/j.scitotenv.2020.141158

Yasar, N. (2017). The relationship between energy consumption and economic growth: Evidence from different income country groups. International Journal of Energy Economics and Policy, 7(2), 86-97. 